\title{
The Comparative Study of the E-government Application in Promoting Local Tourism in China
}

\author{
Wei Zhang \\ Xi'an International University, Xi'an, Shaanxi, China \\ msr0415@163.com
}

\begin{abstract}
The internet revolution and advances in information and communication technologx (ICT) have dramatically changed how citizens and business interact with their governmen. Almost all the government website supply the local tourism information since the tourism is becoming increasingly important for local economic development. This paper is an attempt to compare the current development of the e-government in terms of improving the local tourism industry between the eastern and western medium-sized cities in China.
\end{abstract}

Keywords: E-government, Local tourism industry, Comparative, China

\section{Introduction}

E-government refers to the use of information and communication technology by governments to provide digital services t6 entizens, goveroment employees, business and other agencies online through the internet at local, national or international level. There are many benefits to transforming traditional pablic serviges into e-government services, including costeffective delivery of service, integration of service, reduction in administrative costs, a single integrated view of citizens across all government service, and faster adaptation to citizens' needs [1, 2].The advantages of e-government in timeliness, responsiveness, and cost containment are substantial. For example, e-government allows for interactions with government without the limitations of time and space imposed by office hours and municipal buildings, resulting in reduction in operation inefficiencies, redundant spending, and excessive paperwork. E-government initiatives are deployed not only to enhance citizen services and cost savings in government administration but also to improve transparency and accountability in government functions.

The benchmarking and assessing e-government is necessary to monitor performance and progress by individual countries and identify areas to improve. The evaluation of egovernment hás been proven to be complex and important in both theory and practice [3-7]. The complexity is mostly due to the multiple perspectives involved, the difficulties in quantifying benefits, and the social and technical context of use.

This study is focused on comparing the application of e-government in promoting local toursm in western and eastern medium-sized cities in China. The remainder of this study is organized as follows. Section 2 introduces the related literature about e-government. Following is a brief introduction about the fuzzy TOPSIS (Theory of Order Preference by Similarity to the Ideal Solution) which is employed in this research. Section 4 describes an empirical study of e-government application evaluation and comparison in promoting local tourism in western and eastern cities in China. Finally, major issues and challenges for local governments in promoting local tourism are examined and discussed. 


\section{Literature Review}

The e-government literature has focused predominantly on implementation [8-15] security and authentication [16-19], technology acceptance [20-23], interoperability and connectivity [24-26], project planning and design [27-30], and procurement and purchasing [31,32].

Huang [33] summarize the differences between traditional government and electronic government, as shown in Table 1:

Table 1. Differences between Traditional and Electronic Government

\begin{tabular}{|l|l|}
\hline Traditional government & E-government \\
\hline $\begin{array}{l}\text { Bureaucratic controls, clear authority } \\
\text { hierarchy }\end{array}$ & $\begin{array}{l}\text { Client service and community empowerment, } \\
\text { leveled/blurred hierarchy }\end{array}$ \\
\hline Process centricity & Customer centricity \\
\hline $\begin{array}{l}\text { Isolated administrative functions and data } \\
\text { collection }\end{array}$ & Integrated resource service and knowledge focus \\
\hline $\begin{array}{l}\text { Functional specialization of units or } \\
\text { geographic bias }\end{array}$ & $\begin{array}{l}\text { Breakdown of unit barrier, government } \\
\text { integration }\end{array}$ \\
\hline $\begin{array}{l}\text { Decision based on uniform rules and awkward } \\
\text { reporting approvals }\end{array}$ & $\begin{array}{l}\text { Decision based on negotiation and implicit } \\
\text { controlsand approvals }\end{array}$ \\
\hline Isolated administrative functions & In egrated resource services \\
\hline Time-consuming process & Rapid streamlined responses \\
\hline Disjointed information technologies & Thtegrated netyork solutions \\
\hline
\end{tabular}

There are many researches focused on the relationship between the tourism and general economic growth. Promoting local tourism through e-government application is an effective way to improve the competitiveness of the local ourism industry [34]. The study of Patelis [35] focused on the efficient implementation of e-government in a tourism sector, as a powerful e-decision supporfystem for tourism demand analysis and forecasting. The related researches show that there is an emerging need for improvement in promoting local tourism through e-government application. Tavana [6] propose a hybrid fuzzy model, based on the group Analytic Network Process (ANP) and TOPSIS, to assess a community's overall egovernment readiness from a Citizen Relationship Management (CIRM) perspective. Hsieh [7] adopt a computational approach suggested in the literature to measure the effectiveness of Taiwan's established, gity and county-level (25 cities and counties, and 1411 governmental units) governments' websites, and their research reveals that the well-developed web services provided by Taiwan's government are apparent in two geographically dispersed cities (north and south) and one county in the northern region of Taiwan. Alawneh [36] identify the key factors that determine Jordanians' e-Satisfaction with Jordan's e-government services portal. Five hypotheses are formulated and five factors are identified (i.e., security and privacy, trust, access (bility, awareness of public services, and quality of public services) that may affect the Jordanians' level of satisfaction towards using the Jordan e-government portal. They also provide insights for both practitioners and governmental policy-makers to enhance egovernment portals via accounting diverse factors of technical, behavioral, managerial, and motivational aspects.

\section{Methodology}

To describe the evaluation method clearly, let us present the procedure of fuzzy TOPSIS. We first formulate a Fuzzy Multiple Criteria Decision Making (FMCDM) problem about the 
comparative evaluation of value creation strategy performance. The FMCDM problem involves $m$ alternatives, which are evaluated on $n$ criteria.

The problem can be modeled: $R=\left[R_{i j}\right]_{m \times n}$

In the evaluating process, according to Herrera [37] the weights expressed with the linguistic terms, represent the important degrees of criteria from experts via surveys on subjective assessments. These linguistic terms are categorized into very low (VL), low (L), medium $(\mathrm{M})$, high $(\mathrm{H})$ and very high $(\mathrm{VH})$. Assume that all linguistic terms can be transferred into triangular fuzzy numbers, and these fuzzy numbers are limited in $[0,1]$. The values of these representative indices are set into performance ratings and the setting method is expressed as follows. Let $\mathrm{b}_{\mathrm{ij}}(\mathrm{e})$ indicate the value of representative index $j$ of alternative $i$ on the period $e$, where $i=1,2, \ldots, m ; j=1,2, \ldots, n ; e=1,2, \ldots, t$. Define

$$
R_{i j}=\left(r_{i j}^{l}, r_{i j}^{m}, r_{i j}^{r}\right)
$$

Where $r_{i j}^{l}=\min \left\{b_{i j}(e) \mid e=1,2, \ldots, t\right\}$,

$$
r_{i j}^{m}=\frac{1}{t} \sum_{e=1}^{t} b_{i j}(e), r_{i j}^{r}=\max \left\{b_{i j}(e) \mid e=1,2, \ldots, t\right\}
$$

After constructing the fuzzy decision matrix, it is normalized.

As $b_{i j}(e)$ is benefit item

$g_{i j}^{l}=\frac{b_{i j}^{l}-\min _{i} b_{i j}^{l}}{\max _{i} b_{i j}^{r}-\min _{i} b_{i j}^{l}}, g_{i j}^{m}=\frac{b_{i j}^{m}-\min _{i} b_{i j}^{l}}{\max _{i} b_{i j}^{r}-\min _{i} b_{i j}} g_{i j}^{\max _{i} b_{i j}-\min _{i} b_{i j}^{l} b_{i j}^{l}}$

As $b_{i j}(e)$ is cost item, then

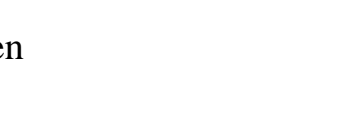

$g_{i j}^{l}=\frac{\max _{i} b_{i j}^{r}-b_{i j}^{l}}{\max _{i} b_{i j}^{r}-\min _{i} b_{i j}^{l}}, g_{i j}^{m}=\frac{\max _{i} b_{i j}^{r}-b_{i j}^{m}}{\max _{i j}^{r}-\min _{i} b_{i j}^{l}}, g_{i j}^{r}=\frac{\max _{i} b_{i j}^{r}-b_{i j}^{r}}{\max _{i} b_{i j}^{r}-\min _{i} b_{i j}^{l}}$

By Up and Lo, anti-ideal and ideal solutions of alternatives are found. Let

$A^{-}=\left[G_{1}^{-}, G_{2}^{-}, \ldots, G_{n}^{-}\right]$and $A=\left[G_{1}^{+}, G_{2}^{+}, \ldots, G_{n}^{+}\right]$be the anti-ideal and ideal solutions respectively, where $G_{(j)}-\operatorname{Lo}\left\{G_{i j} \mid i=1,2, \ldots, m\right\}=\left(g_{j}^{l-}, g_{j}^{m-}, g_{j}^{r-}\right)$ and

$G_{j}^{+}=U p\left\{G_{i j} \mid i=\{2, \ldots, m\}=\left(g_{j}^{l+}, g_{j}^{m+}, g_{j}^{r+}\right)\right.$

for $\mathrm{j}=1,2 . \mathrm{n}$

Assume that $d_{i j}^{-}$and $d_{i j}^{+}$indicate the distance from $\mathrm{G}_{i j}$ to $G_{j}^{-}$and $G_{j}^{+}$, respectively, where

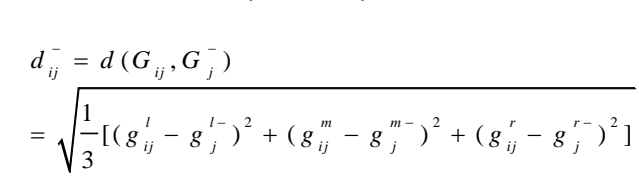

and

$$
\begin{aligned}
& d_{i j}^{+}=d\left(G_{i j}, G_{j}^{+}\right) \\
& =\sqrt{\frac{1}{3}\left[\left(g_{i j}^{l}-g_{j}^{l+}\right)^{2}+\left(g_{i j}^{m}-g_{j}^{m+}\right)^{2}+\left(g_{i j}^{r}-g_{j}^{r+}\right)^{2}\right]}
\end{aligned}
$$


for $i=1,2 \ldots, m ; j=1,2 \ldots, n$

Let $w_{j k}=\left(w_{j k}^{l}, w_{j k}^{m}, w_{j k}^{r}\right)$ be a triangular fuzzy number among which the weight of criterion $c_{j}$ is expressed with linguistic term by expert $E_{k}$, and then set into the fuzzy number, where $j$ $=1,2, \ldots, n ; k=1,2, \ldots, p$. Assume $W_{j}$ to be the average weight of criterion $C_{j}$, so

$$
W_{j}=\left(w_{j}^{l}, w_{j}^{m}, w_{j}^{r}\right)=(1 / p) \otimes\left(W_{j 1} \oplus W_{j 2} \oplus \ldots \oplus W_{j p}\right), j=1,2, \ldots, m
$$

Where $w_{j}^{l}=\sum_{k=1}^{p} w_{j k}^{l} / p, w_{j}^{m}=\sum_{k=1}^{p} w_{j k}^{m} / p, w_{j}^{r}=\sum_{k=1}^{p} w_{j k}^{r} / p$

Let $D_{i}^{-}$and $D_{i}^{+}$indicate the weighted distance from alternative $A_{i}$ to anti-ideal solution $A^{-}$and ideal solution $A^{+}$respectively. Define

$$
D_{i}^{-}=\sum_{j=1}^{n} W_{j} \otimes d_{i j}^{-} \text {and }_{D_{i}^{+}}=\sum_{j=1}^{n} W_{j} \otimes d_{i j}^{+},
$$

$i=1,2, \ldots, m$ Let $N D^{-}=\operatorname{Lo}\left\{D_{i}^{-} \mid i=1,2, \ldots, m\right\}, N D^{+}=U p\left\{D_{i}^{-} \mid i=12 \ldots, m\right\}, P D=\operatorname{Vo}\left\{D_{i}^{+} \mid i=1,2, \ldots, m\right\}$
and $P D^{+}=U p\left\{D_{i}^{+} \mid i=1,2, \ldots, m\right\}$

Thus we assume that anti-ideal and ideal solutions of $\left[D_{i}^{-}\left(D^{+}\right]\right.$are $\left[N D^{-}, P D^{+}\right]$and $\left[N D^{+}\right.$, $\left.P D^{-}\right]$. Let $A_{i}^{-}$and $A_{i}^{+}$denote the distance sưmmares from $\left[D_{i}^{-}, D_{i}^{+}\right]$to $\left[N D^{-}, P D^{+}\right]$and $\left[N D^{+}, P D\right.$ ], respectively, so $A_{i}^{-}=d\left(D_{i}^{-}, N D^{-}\right)+d\left(P_{C P}\right)$

and $A_{i}^{+}=d\left(D_{i}^{+}, N D^{+}\right)+d\left(D_{i}^{+}, P D\right.$

Finally, the closeness coefficien $A^{*}$ of alternative $A_{i}$ is defined as $A^{*}=\frac{A_{i}^{-}}{A_{i}^{-}+A_{i}^{+}}, i=1,2, \ldots, m$ The ranking order of alternatives can be derived by their closeness coefficients.

\section{Data Collection and Results Analysis}

This research is focus on the e-government application in western and eastern mediumsized cities in China, so ten kestern cities and ten eastern cities with the population between 300 thousand and 500 thousand are selected.

A pre-designed observation sheet is used to collect all necessary data from the observation. There are five sections in the observation sheet: (1) the demographic information of the city, (2) visual effect of the website, (3) technology features, (4) popularity of the website, and (5) available tourism information on the website. Three raters are participated to make an appropriate rating and each of them needs to evaluate all 10 websites. Based on a pre-test with selected criteria for consistency consideration, the selected items from all websites are rated with the commonly used Little Scale, i.e., from a scale of 1 (being the worst possible scenario) to 5 (neaning excellent) accordingly. The results are summarized as follows: 
Table 2. Summary of Visual Effect of Website

\begin{tabular}{llllll}
\hline 2. Visual effect of the website & \multicolumn{2}{l}{ Eastern cities } & \multicolumn{2}{l}{ Western cities } \\
\hline category & ranking & number & $\%$ & number & $\%$ \\
2.1 Color assortment & Need improvement $(<2.5)$ & 1 & 10 & 2 & 20 \\
& Satisfied $(\geq 2.5)$ & 9 & 90 & 8 & 80 \\
Total & & 10 & 100 & 10 & 100 \\
2.2 Website structures & Need improvement $(<2.5)$ & 2 & 20 & 3 & 30 \\
& Satisfied $(\geq 2.5)$ & 8 & 80 & 7 & 70 \\
Total & & 10 & 100 & 10 & 100 \\
2.3 Visual attraction & Need improvement $(<2.5)$ & 2 & 20 & 2 & 20 \\
Total & Satisfied $(\geq 2.5)$ & 8 & 80 & 8 & 80 \\
2.4 Multimedia & & 10 & 100 & 10 & 100 \\
Total & Need improvement $(=3)$ & 7 & 70 & 8 & 80 \\
2.4 .1 Video & Satisfied $(=5)$ & 3 & 30 & 2 & 20 \\
2.4 .2 Photo & Exist in website $(1)$ & 10 & 100 & 10 & 100 \\
2.4 .3 Text & No Exist in website $(0)$ & 2 & 80 & 8 & 80 \\
& Exist in website $(1)$ & 10 & 10 & 2 & 20 \\
& No Exist in website $(0)$ & 0 & 0 & 0 & 0 \\
& Exist in website $(1)$ & 10 & 100 & 10 & 100 \\
& No Exist in website $(0)$ & 0 & 0 & 0 & 0 \\
\hline
\end{tabular}

As shown in Table 2, there is not obvious gap between the western cities and eastern cities in terms of visual effect of the e-government websites. However, more than $70 \%$ of the selected cities need to improve the multimedia applications.

Table 3. Summary of Technology Features of Website

\begin{tabular}{|c|c|c|c|c|}
\hline \multirow{4}{*}{$\begin{array}{l}\text { 3. Website performance } \\
\text { category } \\
\begin{array}{l}\text { 3.1 Average opening } \\
\text { time of main page }\end{array} \\
\text { Time-consuming }(<5.5 \mathrm{~s})\end{array}$} & \multicolumn{2}{|c|}{ Eastern cities } & \multicolumn{2}{|c|}{ Western cities } \\
\hline & number & $\%$ & number & $\%$ \\
\hline & 7 & 70 & 6 & 60 \\
\hline & 3 & 30 & 4 & 40 \\
\hline Total & 10 & 100 & 10 & 100 \\
\hline Time consuming $(<3.0 \mathrm{~s})$ & 4 & 40 & 3 & 30 \\
\hline $\begin{array}{l}\text { time of main tab on the Time-consuming }(\geq 3.0 \mathrm{~s}) \\
\text { main page }\end{array}$ & 6 & 60 & 7 & 70 \\
\hline Total & 10 & 100 & 10 & 100 \\
\hline No Broken Links (1) & 2 & 20 & 3 & 30 \\
\hline opening the main page Exist Broken Links (0) & 8 & 80 & 7 & 70 \\
\hline 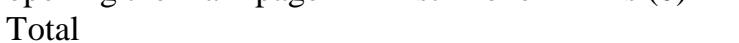 & 10 & 100 & 10 & 100 \\
\hline
\end{tabular}

Since the leadtime for opening a webpage has been ranked very important by internet users, the average opening leadtime of main pages and main tab on the main page are used to evaluate the major technology feature of all observed websites. As shown in Table 3, the average leadtime of opening main page is quite slow, and more than $70 \%$ cities have the problems with opening the main pages. 
Table 4. Summary of Popularity of Websites

\begin{tabular}{|c|c|c|c|c|c|}
\hline \multicolumn{2}{|c|}{ 4. popularity of the website } & \multicolumn{2}{|c|}{ Eastern cities } & \multicolumn{2}{|c|}{ Western cities } \\
\hline category & ranking & number & $\%$ & number & $\%$ \\
\hline \multirow[t]{2}{*}{ 4.1 Pageviews } & Amount $(<500000)$ & 0 & 0 & 3 & 30 \\
\hline & Amount $(\geq 500000)$ & 10 & 100 & 7 & 70 \\
\hline Total & & 10 & 100 & 10 & 100 \\
\hline \multirow[t]{2}{*}{$\begin{array}{l}4.2 \text { Percentage of } \\
\text { visiting the main page }\end{array}$} & $\begin{array}{l}\text { Only visit the homepage }(< \\
5 \%)\end{array}$ & 7 & 70 & 7 & 70 \\
\hline & Others $(\geq 5 \%)$ & 3 & 30 & 3 & 30 \\
\hline Total & & 10 & 100 & 10 & 100 \\
\hline 4.3 Average visit time & Time on site $(<2.0 \mathrm{~s})$ & 4 & 40 & 6 & 60 \\
\hline of each webpage & Time on site $(\geq 2.0 \mathrm{~s})$ & 6 & 60 & 4 & \\
\hline Total & & 10 & 100 & 10 & \\
\hline $4.4 \mathrm{WIF}$ & $\mathrm{WIF}(<3)$ & 5 & 50 & 7 & 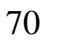 \\
\hline & $\mathrm{WIF}(\geq 3)$ & 5 & 50 & & 0 \\
\hline Total & & 10 & 100 & 10 & 100 \\
\hline
\end{tabular}

In this research, based on the related available literat re, four measures are employed to assess the popularity of the selected websites: (a) online traffic Fank, (b) the percentage of visitor only visiting main page, (c) average visit time, and most importantly, (d) Web Impact Factor (WIF). Currently, WIFhas been used as a quantitative tool for ranking, evaluating, categorizing, and comparing web sites, web pages, web domains and sub-domains in the IT industry. The WIF of a website is determined by the total number of other websites linked to this specific website divided by the total available websites online. A clear indication here is that half of observed websites have a WIF less than 3, implying that there are very limited websites outside have a link to those local government websites.

Table 5. Summary of Available Tourism Information of Website

\begin{tabular}{|c|c|c|c|c|c|}
\hline \multirow{2}{*}{\multicolumn{2}{|c|}{$\begin{array}{l}\text { 5. tourism content of the webstie } \\
\text { category }\end{array}$}} & \multicolumn{2}{|c|}{ Eastern cities } & \multicolumn{2}{|c|}{ Western cities } \\
\hline & & number & $\%$ & number & $\%$ \\
\hline 5.1 is "to & Exist (1) & 8 & 80 & 9 & 90 \\
\hline main & Non exist (0) & 2 & 20 & 1 & 10 \\
\hline Total & & 10 & 100 & 10 & 100 \\
\hline $5.2 \mathrm{O}$ & Exist (1) & 8 & 80 & 4 & 40 \\
\hline & Non exist (0) & 2 & 20 & 6 & 60 \\
\hline Total & & 10 & 100 & 10 & 100 \\
\hline 5.3 E-mail & Exist (1) & 1 & 10 & 0 & 0 \\
\hline & Non exist (0) & 9 & 90 & 10 & 100 \\
\hline Total & & 10 & 100 & 10 & 100 \\
\hline 5.4 Online help & Exist (1) & 7 & 70 & 10 & 100 \\
\hline & Non exist (0) & 3 & 30 & 0 & 0 \\
\hline & & 10 & 100 & 10 & 100 \\
\hline 5.5 Message board & Exist (1) & 9 & 90 & 7 & 70 \\
\hline & Non exist (0) & 1 & 10 & 3 & 30 \\
\hline Total & & 10 & 100 & 10 & 100 \\
\hline 5.7 Website update frequency & $\begin{array}{l}\text { Need improvement }( \\
<2.5)\end{array}$ & 2 & 20 & 5 & 50 \\
\hline & Satisfied $(\geq 2.5)$ & 8 & 80 & 5 & 50 \\
\hline Total & & 10 & 100 & 10 & 100 \\
\hline 5.8 Introduction of tourist & $\begin{array}{l}\text { Need improvement }( \\
<2.5)\end{array}$ & 4 & 40 & 2 & 20 \\
\hline
\end{tabular}


Total

5.9 Attraction routes

Total

5.10 Hotels

Total

5.11 Shopping

Total

5.14 Local weather forecast

Total

5.15 Multi-languages

Total

\begin{tabular}{lllll} 
Satisfied $(\geq 2.5)$ & 6 & 60 & 8 & 80 \\
& 10 & 100 & 10 & 100 \\
Need improvement ( & 6 & 60 & 3 & 30 \\
$<2.5)$ & & & & \\
Satisfied $(\geq 2.5)$ & 4 & 40 & 7 & 70 \\
& 10 & 100 & 10 & 100 \\
Need improvement ( & 9 & 90 & 10 & 100 \\
$<2.5)$ & & & & \\
Satisfied $(\geq 2.5)$ & 1 & 10 & 0 & 0 \\
& 10 & 100 & 10 & 100 \\
Need improvement ( & 9 & 90 & 3 & 30 \\
$<2.5)$ & & & & \\
Satisfied $(\geq 2.5)$ & 1 & 10 & 7 & 70 \\
& 10 & 100 & 10 & 100 \\
Only day Weather $(3)$ & 3 & 30 & 4 & 40 \\
Future weather $(5)$ & 7 & 70 & 6 & 60 \\
& 10 & 100 & 10 & 100 \\
Only Chinese (0) & 9 & 90 & 9 & 90 \\
Multi-languages $(1)$ & 1 & 10 & 1 & 10 \\
& 10 & 100 & 10 & 100 \\
\hline
\end{tabular}

The most important and related data collected in this research, perhaps, is the current available tourism information on the websites, in terms of promoting local tourism through egovernment application, which are summarized in Table-5. It is can be seen from this Table that comparing with the eastern cities the development of the e-government application is more slowly. For example, only two of the seleeted eastern cities don't supply the office phone, while more than half of the selected western cities don't supply the office phone.

To further identify the relative importance of the four major measurements discussed in the earlier section for their effects on the promoting local tourism through e-government application, the fuzzy TOPSIS, as a quantitative tool, is employed in this research. The decision problem consists of three levels: the objective of the problem is the highest level, while in the second level, the aspects are listed including visual effect of the e-government websites, technology performance of the website, popularity of the website and the tourism information online. The sub-citeria are listed in the third level including nineteen criteria as shown in Table 6.

Table 6. Criteria for Measuring E-government Application in Promoting
Local Tourism
\begin{tabular}{|l|l|l|}
\hline Goal & Aspects & Criteria \\
\hline & $\begin{array}{l}\text { Visual effect of } \\
\text { the website }\end{array}$ & $\begin{array}{l}C_{1} \text { Color assortment } \\
C_{2} \text { Website structures } \\
C_{3} \text { Visual attraction } \\
C_{4} \text { Multi-media }\end{array}$ \\
\cline { 2 - 3 } $\begin{array}{l}\text { E-government in } \\
\text { promoting local } \\
\text { tourism }\end{array}$ & $\begin{array}{l}\text { Technology } \\
\text { performance of } \\
\text { the website }\end{array}$ & $\begin{array}{l}C_{5} \text { Average leadtime of main page } \\
C_{6} \text { Average leadtime of main tab on the main page } \\
C_{7} \text { Problems with opening the main page }\end{array}$ \\
\hline
\end{tabular}




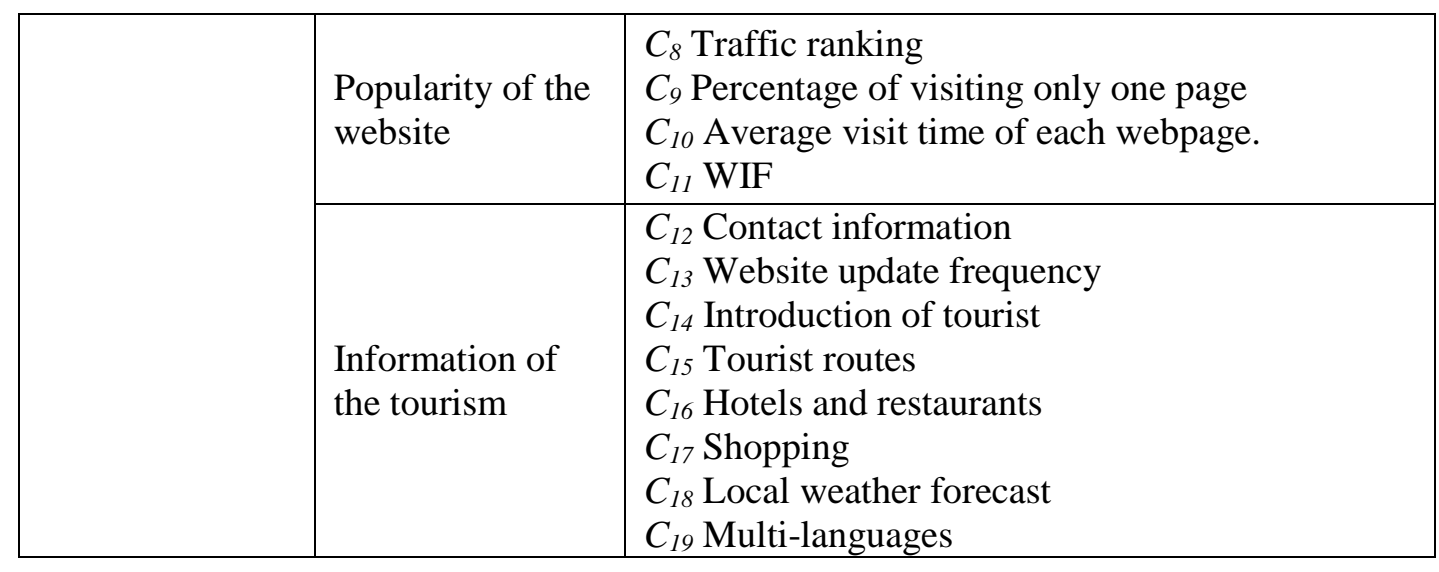

The weights of the representative criteria are given with linguistic terms, i.e, VL, L, M, H, and $\mathrm{VH}$, employed by four experts $\mathrm{E}_{1}, \mathrm{E}_{2}, \mathrm{E}_{3}$ and $\mathrm{E}_{4}$, as shown in Table 7.

Table 7. The Linguistic Weights Given by Five Experts

\begin{tabular}{|c|c|c|c|c|}
\hline Sub- Criteria & $\mathrm{E} 1$ & $\mathrm{E} 2$ & $\mathrm{E} 3$ & $\mathrm{E}$ \\
\hline$S C_{1}$ & $\mathrm{H}$ & $\mathrm{M}$ & $\mathrm{H}$ & $\mathrm{VH}$ \\
\hline$S C_{2}$ & $\mathrm{H}$ & $\mathrm{H}$ & $\mathrm{VH}$ & $\mathrm{H}$ \\
\hline$S C_{3}$ & $\mathrm{M}$ & $\mathrm{H}$ & $\mathrm{VH}$ & $\mathrm{M}$ \\
\hline$S C_{4}$ & $\mathrm{~L}$ & $\mathrm{VL}$ & $\mathrm{M}$ & $\mathrm{M}$ \\
\hline$S C_{5}$ & $\mathrm{M}$ & $\mathrm{L}$ & $\mathrm{VL}$ & $\mathrm{L}$ \\
\hline$S C_{6}$ & $\mathrm{~L}$ & $\mathrm{VI}$ & $\mathrm{VL}$ & $\mathrm{L}$ \\
\hline$S C_{7}$ & $\mathrm{~V}$ & $\mathrm{M}$ & $\mathrm{L}$ & $\mathrm{L}$ \\
\hline$S C_{8}$ & $\mathrm{VH}$ & $\mathrm{H}$ & $\mathrm{M}$ & $\mathrm{H}$ \\
\hline$S C_{9}$ & $\mathrm{M}$ & $\mathrm{H}$ & $\mathrm{M}$ & $\mathrm{H}$ \\
\hline$S C_{10}$ & $\mathrm{H}$ & $\mathrm{M}$ & $\mathrm{H}$ & $\mathrm{H}$ \\
\hline$S C_{1}$ & $\mathrm{VH}$ & $\mathrm{H}$ & $\mathrm{VH}$ & $\mathrm{VH}$ \\
\hline$S C_{12}$ & $\mathrm{~V}$ & $\mathrm{VL}$ & $\mathrm{VL}$ & $\mathrm{L}$ \\
\hline$S C_{13}$ & $\mathrm{H}$ & $\mathrm{M}$ & $\mathrm{H}$ & $\mathrm{H}$ \\
\hline$S C_{14}$ & $\mathrm{M}$ & $\mathrm{H}$ & $\mathrm{H}$ & $\mathrm{H}$ \\
\hline$S C_{15}$ & $\mathrm{M}$ & $\mathrm{L}$ & $\mathrm{M}$ & $\mathrm{M}$ \\
\hline$S C_{16}$ & $\mathrm{M}$ & $\mathrm{L}$ & $\mathrm{M}$ & $\mathrm{L}$ \\
\hline$S C_{17}$ & $\mathrm{~L}$ & $\mathrm{~L}$ & $\mathrm{VL}$ & $\mathrm{L}$ \\
\hline$S C_{8}$ & $\mathrm{M}$ & $\mathrm{H}$ & $\mathrm{L}$ & $\mathrm{M}$ \\
\hline$S C_{19}$ & $\mathrm{H}$ & $\mathrm{M}$ & $\mathrm{M}$ & $\mathrm{L}$ \\
\hline
\end{tabular}

In the next step, the raters are asked to evaluate the twenty cities (ten eastern cities and ten western cities, and considering the limit of the page, only part of the results are shown in Table 8.

\section{Table 8. Part of the Evaluation Results using Fuzzy Linguistic Variables}

\begin{tabular}{|c|c|c|c|c|c|c|c|c|c|}
\hline City & No. & $S C_{1}$ & $S C_{2}$ & $S C_{3}$ & $S C_{4}$ & $S C_{5}$ & $S C_{6}$ & $S C_{7}$ & $S C_{8}$ \\
\hline \multirow{5}{*}{$\begin{array}{c}\text { Eastern } \\
\text { cities }\end{array}$} & 1 & $\mathrm{M}$ & $\mathrm{H}$ & $\mathrm{M}$ & $\mathrm{M}$ & $\mathrm{H}$ & $\mathrm{H}$ & $\mathrm{VH}$ & $\mathrm{L}$ \\
\cline { 2 - 11 } & 2 & $\mathrm{H}$ & $\mathrm{M}$ & $\mathrm{L}$ & $\mathrm{VH}$ & $\mathrm{M}$ & $\mathrm{H}$ & $\mathrm{VL}$ & $\mathrm{H}$ \\
\cline { 2 - 10 } & 3 & $\mathrm{~L}$ & $\mathrm{H}$ & $\mathrm{M}$ & $\mathrm{M}$ & $\mathrm{L}$ & $\mathrm{H}$ & $\mathrm{VH}$ & $\mathrm{M}$ \\
\cline { 2 - 11 } & 4 & $\mathrm{H}$ & $\mathrm{M}$ & $\mathrm{M}$ & $\mathrm{VH}$ & $\mathrm{L}$ & $\mathrm{H}$ & $\mathrm{VL}$ & $\mathrm{L}$ \\
\cline { 2 - 10 } & 6 & $\mathrm{H}$ & $\mathrm{H}$ & $\mathrm{VH}$ & $\mathrm{VH}$ & $\mathrm{M}$ & $\mathrm{M}$ & $\mathrm{VL}$ & $\mathrm{H}$ \\
\cline { 2 - 10 } & & & & $\mathrm{VL}$ & $\mathrm{M}$ & $\mathrm{H}$ & $\mathrm{M}$ & $\mathrm{VL}$ & $\mathrm{VL}$ \\
\hline
\end{tabular}




\begin{tabular}{|c|c|c|c|c|c|c|c|c|c|}
\multirow{5}{*}{} & 7 & $\mathrm{M}$ & $\mathrm{M}$ & $\mathrm{M}$ & $\mathrm{M}$ & $\mathrm{L}$ & $\mathrm{M}$ & $\mathrm{VL}$ & $\mathrm{M}$ \\
\cline { 2 - 10 } & 8 & $\mathrm{M}$ & $\mathrm{M}$ & $\mathrm{L}$ & $\mathrm{M}$ & $\mathrm{L}$ & $\mathrm{L}$ & $\mathrm{VL}$ & $\mathrm{VH}$ \\
\cline { 2 - 10 } & 9 & $\mathrm{M}$ & $\mathrm{M}$ & $\mathrm{M}$ & $\mathrm{M}$ & $\mathrm{M}$ & $\mathrm{H}$ & $\mathrm{VL}$ & $\mathrm{M}$ \\
\cline { 2 - 10 } & 10 & $\mathrm{M}$ & $\mathrm{L}$ & $\mathrm{M}$ & $\mathrm{M}$ & $\mathrm{M}$ & $\mathrm{H}$ & $\mathrm{VL}$ & $\mathrm{VH}$ \\
\hline \multirow{5}{*}{$\begin{array}{c}\text { Western } \\
\text { cities }\end{array}$} & 11 & $\mathrm{M}$ & $\mathrm{M}$ & $\mathrm{M}$ & $\mathrm{M}$ & $\mathrm{H}$ & $\mathrm{H}$ & $\mathrm{VL}$ & $\mathrm{M}$ \\
\cline { 2 - 10 } & 12 & $\mathrm{H}$ & $\mathrm{M}$ & $\mathrm{H}$ & $\mathrm{VH}$ & $\mathrm{M}$ & $\mathrm{H}$ & $\mathrm{VL}$ & $\mathrm{VH}$ \\
\cline { 2 - 10 } & 13 & $\mathrm{M}$ & $\mathrm{M}$ & $\mathrm{M}$ & $\mathrm{M}$ & $\mathrm{M}$ & $\mathrm{H}$ & $\mathrm{VL}$ & $\mathrm{VH}$ \\
\cline { 2 - 10 } & 14 & $\mathrm{M}$ & $\mathrm{M}$ & $\mathrm{M}$ & $\mathrm{M}$ & $\mathrm{M}$ & $\mathrm{H}$ & $\mathrm{VL}$ & $\mathrm{H}$ \\
\cline { 2 - 10 } & 15 & $\mathrm{M}$ & $\mathrm{M}$ & $\mathrm{M}$ & $\mathrm{M}$ & $\mathrm{M}$ & $\mathrm{M}$ & $\mathrm{VH}$ & $\mathrm{VL}$ \\
\cline { 2 - 10 } & 16 & $\mathrm{M}$ & $\mathrm{M}$ & $\mathrm{M}$ & $\mathrm{M}$ & $\mathrm{M}$ & $\mathrm{H}$ & $\mathrm{VL}$ & $\mathrm{H}$ \\
\cline { 2 - 10 } & 17 & $\mathrm{~L}$ & $\mathrm{M}$ & $\mathrm{M}$ & $\mathrm{M}$ & $\mathrm{M}$ & $\mathrm{H}$ & $\mathrm{VL}$ & $\mathrm{L}$ \\
\cline { 2 - 9 } & 18 & $\mathrm{~L}$ & $\mathrm{M}$ & $\mathrm{M}$ & $\mathrm{M}$ & $\mathrm{L}$ & $\mathrm{L}$ & $\mathrm{VL}$ & $\mathrm{VL}$ \\
\cline { 2 - 9 } & 19 & $\mathrm{M}$ & $\mathrm{L}$ & $\mathrm{M}$ & $\mathrm{VH}$ & $\mathrm{VL}$ & $\mathrm{L}$ & $\mathrm{VH}$ & $\mathrm{VL}$ \\
\cline { 2 - 9 } & 20 & $\mathrm{~L}$ & $\mathrm{~L}$ & $\mathrm{~L}$ & $\mathrm{M}$ & $\mathrm{VL}$ & $\mathrm{L}$ & $\mathrm{VH}$ & $\mathrm{L}$ \\
\hline
\end{tabular}

Then the normalized decision matrix is then derived from the original data as follows:

The larger, the better type [38]:

$$
r_{i j}=\frac{\left[x_{i j}-\min \left\{x_{i j}\right\}\right]}{\left[\max \left\{x_{i j}\right\}-\min \left\{x_{i j}\right\}\right]}
$$

The smaller, the better type:

$$
r_{i j}=\frac{\left[\max \left\{x_{i j}\right\}-x_{i j}\right]}{\left[\max \left\{x_{i j}\right\}-\min \left\{x_{i j}\right\}\right]}
$$

The Fuzzy linguistic variable ls then transformed into a Fuzzy triangular membership function as shown in Table 9 , and then the resulting Fuzzy weighted decision matrix can be derived based on Table and the weights identified before. As discussed in 3.3, the positive ideal and negative ideal solutions can be defined as $\tilde{v}_{j}^{+}=(1,1,1)$ and $\tilde{v}_{j}^{-}=(0,0,0) j=1, \cdots, n$. The distance of each alternative from $A^{+}$and $A^{-}$, as well as the similarities to an ideal solution. s obtained in Table 10

Table 9. Part of the Fuzzy Decision Matrix

\begin{tabular}{|c|c|c|c|c|c|c|}
\hline City & No. & $S C_{1}$ & $S C_{2}$ & $S C_{3}$ & $S C_{4}$ & $S C_{5}$ \\
\hline \multirow{5}{*}{$\begin{array}{c}\text { Eastern } \\
\text { cities }\end{array}$} & 1 & $(0.35,0.50,0.65)$ & $(0.55,0.70,0.85)$ & $(0.35,0.50,0.65)$ & $(0.35,0.50,0.65)$ & $(0.55,0.70,0.85)$ \\
\cline { 2 - 7 } & 2 & $(0.55,0.70,0.85)$ & $(0.35,0.50,0.65)$ & $(0.15,0.30,0.45)$ & $(0.75,0.90,1.00)$ & $(0.35,0.50,0.65)$ \\
\cline { 2 - 7 } & 3 & $(0.15,0.30,0.45)$ & $(0.55,0.70,0.85)$ & $(0.35,0.50,0.65)$ & $(0.35,0.50,0.65)$ & $(0.15,0.30,0.45)$ \\
\cline { 2 - 7 } & 4 & $(0.55,0.70,0.85)$ & $(0.35,0.50,0.65)$ & $(0.35,0.50,0.65)$ & $(0.75,0.90,1.00)$ & $(0.15,0.30,0.45)$ \\
\cline { 2 - 7 } & 6 & $(0.55,0.70,0.85)$ & $(0.55,0.70,0.85)$ & $(0.75,0.90,1.00)$ & $(0.75,0.90,1.00)$ & $(0.35,0.50,0.65)$ \\
\cline { 2 - 7 } & 7 & $(0.35,0.50,0.65)$ & $(0.35,0.50,0.65)$ & $(0.35,0.50,0.65)$ & $(0.35,0.50,0.65)$ & $(0.15,0.30,0.45)$ \\
\cline { 2 - 7 } & 8 & $(0.35,0.50,0.65)$ & $(0.35,0.50,0.65)$ & $(0.15,0.30,0.45)$ & $(0.35,0.50,0.65)$ & $(0.15,0.30,0.45)$ \\
\cline { 2 - 7 } & 9 & $(0.35,0.50,0.65)$ & $(0.35,0.50,0.65)$ & $(0.35,0.50,0.65)$ & $(0.35,0.50,0.65)$ & $(0.35,0.50,0.65)$ \\
\cline { 2 - 7 } & 10 & $(0.35,0.50,0.65)$ & $(0.15,0.30,0.45)$ & $(0.35,0.50,0.65)$ & $(0.35,0.50,0.65)$ & $(0.35,0.50,0.65)$ \\
\hline \multirow{5}{*}{} & 11 & $(0.35,0.50,0.65)$ & $(0.35,0.50,0.65)$ & $(0.35,0.50,0.65)$ & $(0.35,0.50,0.65)$ & $(0.55,0.70,0.85)$ \\
\cline { 2 - 7 } & 12 & $(0.55,0.70,0.85)$ & $(0.35,0.50,0.65)$ & $(0.55,0.70,0.85)$ & $(0.75,0.90,1.00)$ & $(0.35,0.50,0.65)$ \\
\cline { 2 - 7 } & 13 & $(0.35,0.50,0.65)$ & $(0.35,0.50,0.65)$ & $(0.35,0.50,0.65)$ & $(0.35,0.50,0.65)$ & $(0.35,0.50,0.65)$ \\
\hline
\end{tabular}




\begin{tabular}{|l|c|c|c|c|c|c|}
\begin{tabular}{|} 
Western \\
cities
\end{tabular} & 14 & $(0.35,0.50,0.65)$ & $(0.35,0.50,0.65)$ & $(0.35,0.50,0.65)$ & $(0.35,0.50,0.65)$ & $(0.35,0.50,0.65)$ \\
\cline { 2 - 7 } & 15 & $(0.35,0.50,0.65)$ & $(0.35,0.50,0.65)$ & $(0.35,0.50,0.65)$ & $(0.35,0.50,0.65)$ & $(0.35,0.50,0.65)$ \\
\cline { 2 - 7 } & 16 & $(0.35,0.50,0.65)$ & $(0.35,0.50,0.65)$ & $(0.35,0.50,0.65)$ & $(0.35,0.50,0.65)$ & $(0.35,0.50,0.65)$ \\
\cline { 2 - 7 } & 17 & $(0.15,0.30,0.45)$ & $(0.35,0.50,0.65)$ & $(0.35,0.50,0.65)$ & $(0.35,0.50,0.65)$ & $(0.35,0.50,0.65)$ \\
\cline { 2 - 7 } & 18 & $(0.15,0.30,0.45)$ & $(0.35,0.50,0.65)$ & $(0.35,0.50,0.65)$ & $(0.35,0.50,0.65)$ & $(0.15,0.30,0.45)$ \\
\cline { 2 - 7 } & 19 & $(0.35,0.50,0.65)$ & $(0.15,0.30,0.45)$ & $(0.35,0.50,0.65)$ & $(0.75,0.90,1.00)$ & $(0.00,0.10,0.25)$ \\
\cline { 2 - 7 } & 20 & $(0.15,0.30,0.45)$ & $(0.15,0.30,0.45)$ & $(0.15,0.30,0.45)$ & $(0.35,0.50,0.65)$ & $(0.00,0.10,0.25)$ \\
\hline
\end{tabular}

Table 10. The Distance of each Alternative from $A^{+}$and $A$

\begin{tabular}{|c|c|c|c|}
\hline No. & $d_{i}^{+}$ & $d_{i}^{-}$ & $C C_{i}$ \\
\hline 1 & 0.151 & 0.184 & 0.550 \\
\hline 2 & 0.177 & 0.159 & 0.473 \\
\hline 3 & 0.200 & 0.135 & 0.402 \\
\hline 4 & 0.223 & 0.112 & 0.334 \\
\hline 5 & 0.104 & 0.231 & 0.689 \\
\hline 6 & 0.183 & 0.153 & 0.455 \\
\hline 7 & 0.202 & 0.133 & 0.397 \\
\hline 8 & 0.130 & 0.205 & 0.613 \\
\hline 9 & 0.169 & 0.167 & 0.497 \\
\hline 10 & 0.194 & 0.141 & 0.422 \\
\hline 11 & 0.156 & 0.180 & 0.536 \\
\hline 12 & 0.160 & 0.175 & 0.522 \\
\hline 13 & 0.132 & 0.204 & 0.607 \\
\hline 14 & 0.171 & 0.164 & 0.490 \\
\hline 15 & 0170 & 0.165 & 0.493 \\
\hline 16 & 0.165 & 0.170 & 0.507 \\
\hline 17 & 0.185 & 0.151 & 0.450 \\
\hline 18 & 0.204 & 0.132 & 0.393 \\
\hline 19 & 0.266 & 0.069 & 0.206 \\
\hline 20 & 0.200 & 0.136 & 0.404 \\
\hline
\end{tabular}

\section{Conclusion}

This research is an attempt to compare and investigate the current issues and development of the application of e-government in promoting local tourism industry for western and eastern medium-sized cities in China. The objectives for this research are threefold: (1) to examine and evaluate the online tourism promotion already implemented; (2) to identify major issues and challenges for their e-government application of those local governments in promoting focal tourism; and (3) to compare the e-government service between the western cities and eastern cities.

The primary data for this research are collected through a comprehensive website evaluation. Fuzzy TOPSIS is employed to evaluate the current online tourism promotion implemented by those selected non-capital city local governments. The data collected from this study show that There is obvious gap between the eastern and western cities, and the egovernment application of western cities is relatively slowly than the eastern cities, imply that there is an emerging need for improvement in promoting local tourism through e-government application. 


\section{References}

[1] V. Venkatesh, F. Chan and J. Thong, "Designing e-government services: key service attributes and citizens' preference structures", Journal of Operations Management, vol. 30, no. 1, (2012), pp.116-133.

[2] A. Akman, A. Yazici, A. Mishraa and Arifoglu. "E-government: a global view and an empirical evaluation of some attributes of citizens", Government Information Quarterly, vol. 22, no. 2, (2005), pp. 239-257.

[3] S. Jones and J. Hughes, "Understanding IS evaluation as a complex social process: A case study of a UK local authority", European Journal of Information Systems, vol. 10, no. 1, (2001), pp. 57-63.

[4] V. Serafeimidis and S. Smithson, "Information systems evaluation in practice: A case study of organizational change", Journal of Information Technology, vol. 15, no. 2, (2000), pp. 93-105.

[5] V. Symons and G. Walsham, "The evaluation of information systems: A critique", Journal of Applied Systems Analysis, vol.15, (1988), pp. 119-132.

[6] M. Tavana, et al., (2013), "A hybrid fuzzy group ANP-TOPSIS framework for assessment of e-government readiness from a CRM perspective”, Information \& Management, vol. 50, no. 7, pp. 383-397.

[7] P. H. Hsieh, et al., "Assessing web services of emerging economies in an Eastern country-Taiwan's"egovernment", Government Information Quarterly, vol. 30, no. 3, (2013), pp. 267-276.

[8] C. Chan and S. Pan, "User engagement in e-government systems implementation: a comparative case study of two Singaporean e-government initiatives", The Journal of Strategic Information Sys ems, yol. 17, no. 2, (2008), pp. 124-139.

[9] C. Chan, Y. Lau and S. Pan, "E-government implementation: a mâroanalysis of Singapore's e-government initiatives", Government Information Quarterly, vol. 25, no. 2, (2008), pp.239-255.

[10] A. Chen, S. Pan, J. Zhang, W. Huang and S. Zhu, "Managing e-government Implementation in China: a process perspective", Information and Management, vol. 46, no. 4, (2009) pp. 203-212.

[11] R. Heeks, "E-Government as a carrier of context", Journal of Public Policy, vol. 25, (2005), pp. 51-74.

[12] K. Layne and J. Lee, "Developing fully functional e-government; a four stage model", Government Information Quarterly, vol. 18, (2001), pp. 122-136.

[13] S. Liao and H. Jeng, "E-government implementation: business contract legal support for Taiwanese businessmen in Mainland China", Government Information Quarterly, vol. 22, no. 3, (2005), pp. 505-524.

[14] E. Nagi and M. Hamdan "Computerization and e-Government implementation in Jordan: challenges, obstacles and successes”, Government Information Quarterly, vol. 26, no. 4, (2009), pp. 577-583.

[15] W. Rose and G. Grant, "Critical issues pertaining to the planning and implementation of E-Government initiatives", Government Information Quarterly, vol 27, no. 1, (2010), pp. 26-33.

[16] A. Kaliontzoglou, P. Sklavos, T. Karantjias and D. Polemi, "A secure e-Government platform architecture for small to medium sized publicorganizations", Electionic Commerce Research and Applications, vol. 4, no. 2, (2005), pp.174-186.

[17] H. Tanaka, K. Matsuuna and O. Sudoh, "Vulnerability and information security investment: an empirical analysis of e-local government in Japan, Journal of Accounting and Public Policy, vol. 24 , no. 1, (2005), pp. 37-59.

[18] J. Zhao, S Zhao and S. Zhao "Opportunities and threats: a security assessment of state e-government websites", Government Information Quarterly, vol. 27, no. 1, (2010), pp. 49-56.

[19] D. Zissis and D. Lekkas, "Securing e-Government and e-Voting with an open cloud computing architecture", Government Information Quarterly, vol. 28, no. 2, (2011), pp. 239-251.

[20] S. Hung, C. Chang and T. Yu, "Determinants of user acceptance of the e- Government services: the case of online tax filing and payment system", Government Information Quarterly, vol. 23, no. 1, (2006), pp. 97-122.

[21] J. Lee, H. Kim and M. Ahn, "The willingness of e-Government service adoption by business users: the role of offline sêrvice quality and trust in technology", Government Information Quarterly, vol. 28, no.2, (2011), pp. $222-230$.

[22] F. Lin S. Fofanah and D. Liang, "Assessing citizen adoption of e-Government initiatives in Gambia: a validation of the technology acceptance model in information systems success", Government Information Quarterly, vol. 28, no. 2, (2011), pp. 271-279.

[23] S. Shyu and J. Huang, "Elucidating usage of e-government learning: a perspective of the extended technology acceptance model", Government Information Quarterly, vol. 28, no. 4, (2011), pp. 491-502.

[24] S. Choi and A. Whinston, "Benefits and requirements for interoperability in the electronic marketplace", Technology in Society, vol. 22, no. 1, (2000), pp. 33-44.

[25] P. Gottschalk, "Maturity levels for interoperability in digital government", Government Information Quarterly, vol. 26. no. 1, (2009), pp. 75-81.

[26] P. Jaeger, J. Bertot, C. McClure and L. Langa, (2006), "The policy implications of internet connectivity in public libraries", Government Information Quarterly, vol. 23, no. 1, pp. 123-141.

[27] C. Batini, G. Viscusi and D. Cherubini, "GovQual: a quality driven methodology for E-Government project planning”, Government Information Quarterly, vol. 26, no. 1, (2009), pp. 106-117. 
[28] I. Ruuska and R. Teigland, "Ensuring project success through collective competence and creative conflict in public-private partnerships-A case study of Bygga Villa, a Swedish triple helix e-government initiative", International Journal of Project Management, vol. 27, no. 4, (2009), pp. 323-334.

[29] D. Sarantis, Y. Charalabidis and D. Askounis, "A goal-driven management framework for electronic government transformation projects implementation", Government Information Quarterly, vol. 28, no. 1, (2011), pp. 117-128.

[30] M. Sharifi and A. Manian, "The study of the success indicators for pre-implementation activities of Iran's EGovernment development projects”, Government Information Quarterly, vol. 27, no. 1, (2010), pp. 63-69.

[31] G. Concha, H. Astudillo, M. Porru and C. Pimenta, "E-Government procurement observatory, maturity model and early measurements", Government Information Quarterly, vol. 29, no. 1, (2012), pp. 543-550.

[32] C. Hardy and S. Williams, "E-government policy and practice: a theoretical and empirical exploration of public e-procurement", Government Information Quarterly, vol. 25, no. 2, (2008), pp. 155-180.

[33] W. Huang, Y. Chen and K. L. Wang, "E-government Development \& Implementation", igi-global.com, (2002).

[34] J. Yang, E. Harris and M. Whitfield, "E-government application in promoting local tourism: an empirical study”, Electronic Government, an International Journal, vol. 6, no. 1, (2009), pp. 54-62.

[35] A. Patelis, et al., "Tourism planning decision support within an e-government framework" Electronic Government: An International Journal, vol.2, no. 2, (2005), pp. 134-143.

[36] A. Alawneh, H. Al-Refai and K. Batiha, "Measuring user satisfaction ffom e-Government services: Lessons from Jordan”, Government Information Quarterly, vol. 30, (2013), pp. $277-288$.

[37] F. Herrera, E. Herrera-Viedma and J. L. Verdegay, "A model of consensus in group decision making under linguistic assessments", Fuzzy Sets and Systems, vol. 78, (1996), pp. 73-80,

[38] T. Yang and C.C. Hung, "Multiple-attribute decision-making methods for plant layout design problem", Robotics and Computer-integrated manufacturing, vol. 23, (2007), pp. 126-137.

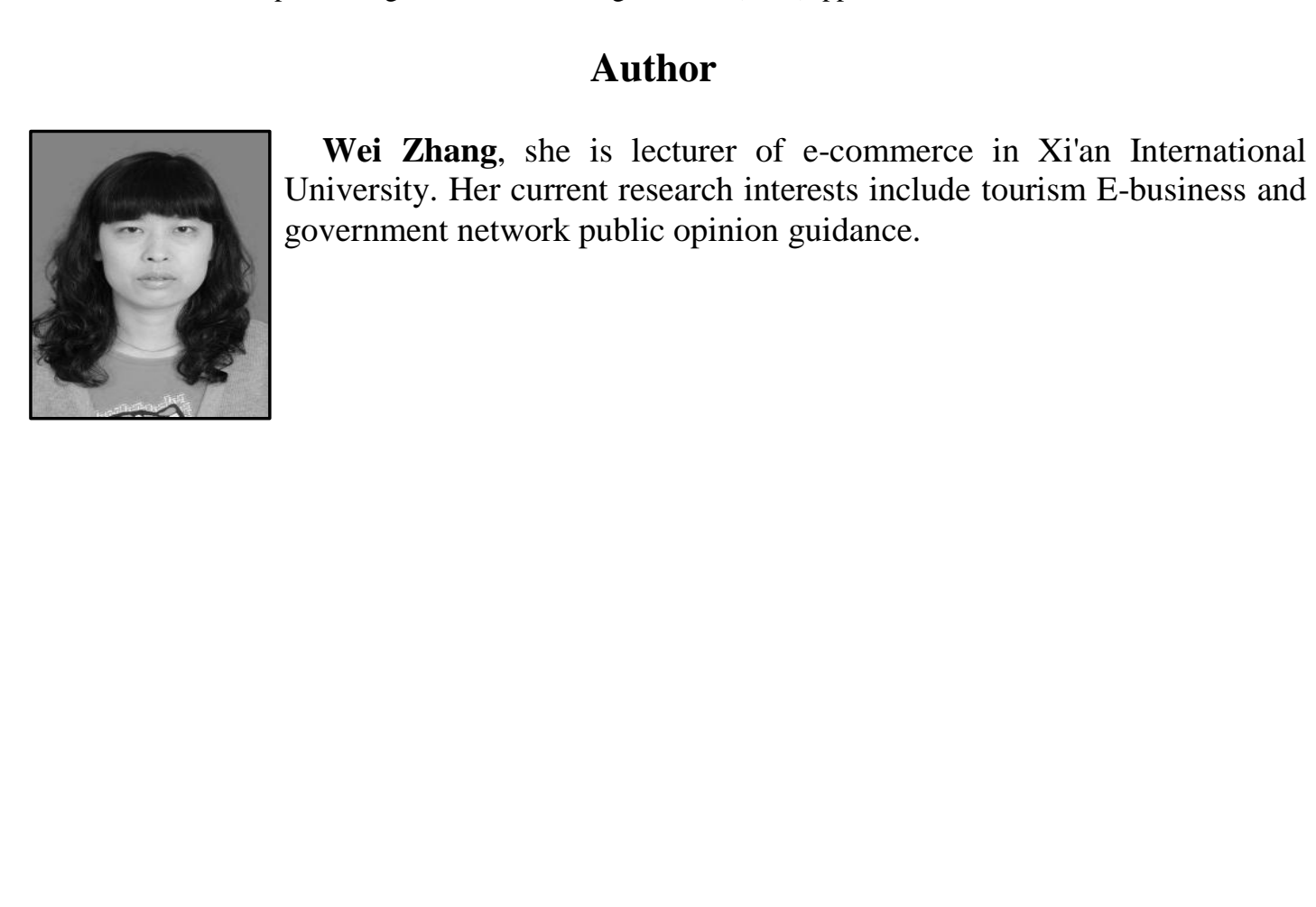

